
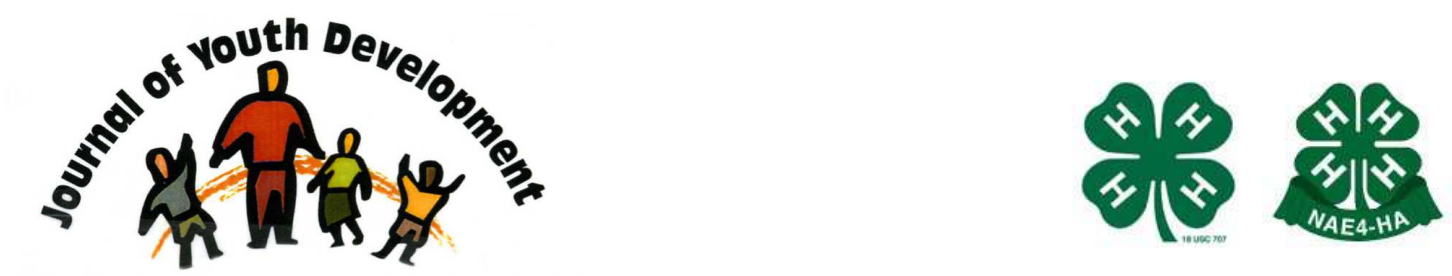

Bridging Research \& Practice

\title{
Teen Ambassador Leadership Kit (TALK)
}

\author{
Donna R. Gillespie \\ University of Idaho Extension, Minidoka County \\ Rupert, ID \\ donna@uidaho.edu
}




\title{
JOURNAL OF YOUTH DEVELOPMENT \\ bridging research and practice

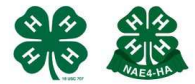

Volume 7, Number 4, Winter 2012

Article 120704PA002

\section{Teen Ambassador Leadership Kit (TALK)}

\author{
Donna R. Gillespie \\ University of Idaho Extension, Minidoka County
}

\begin{abstract}
Teen Ambassador Leadership Kit, (TALK), is an annual weekend retreat designed for teens interested in promoting and marketing 4- $\mathrm{H}$ in their communities. TALK organizers felt teens would benefit from an intensive weekend retreat focused on communication. TALK produces a network of educated and excited 4-H teens that are available to help with $4-\mathrm{H}$ promotion and marketing. Participants arrive on Friday evening for team building activities, on Saturday they participate in one of the workshops offered and on Sunday morning each workshop group has the opportunity to share their completed projects and what they learned. At the conclusion of the retreat, teens are designated "County 4-H Ambassadors" and certificates of completion, professional business cards and polo shirts are presented. The TALK teen participants return home to share what they learned with their local county 4-H staff and help promote and market 4-H in their communities.
\end{abstract}

\section{Introduction}

The Idaho 4-H Teen TALK (Teen Ambassador Leadership Kit) Retreat inspires and builds confidence in youth who want to learn how to promote 4- $\mathrm{H}$ in their communities, as well as for those who want to plan and organize 4-H events. Tufts University studies on The Positive Development of Youth, Wave 8, (Lerner, Lerner \& Colleagues, 2011) includes the 6th "C", contribution, and notes that 4- $\mathrm{H}$ youth are 3.4 times more likely to actively contribute to their communities when compared with youth who do not participate in 4-H. TALK, an annual statewide retreat, was designed to encourage and aide teen's willingness to contribute and teach the life skills they need to organize community events and promote 4-H Youth Development.

In their research looking at 4-H enrollment and retention, Harder, Lamm, Lamm, Rose and Rask (2005), observed that the steady decline in the member population begins at age twelve and 
continues on through age eighteen. After considering the factors that affect older 4-H member's choices to remain engaged, Gill, Ewing, and Bruce (2010), recommended designing programs and activities that promote personal growth and life skill building. Idaho 4-H statistics from 2011 show only $12 \%$ of total enrolled youth are currently in grades 10-12, (Idaho ES 237), nationwide numbers from the Annual 4-H Youth Development Enrollment Report (2003) show $8 \%$ of the total at this grade level. With this in mind, the TALK organizers felt teens would benefit directly from an intensive weekend retreat focusing on communication that was both challenging and fun.

The Tufts University study, (Lerner, Lerner, \& Colleagues, 2011), found that youth in grades five through eleven show the same likelihood of contribution as do twelfth graders. In Idaho, 4-H teens ninth through twelfth grade, have an opportunity to attend the Idaho 4-H Teen Ambassador training each fall and learn skills in public speaking (Shelstad, \& Peutz, 2009). Younger teens in Idaho have indicated an interest in leadership roles and needed a venue to learn communication skills; the TALK retreat was created to meet this need. An alternative training, such as TALK, was also needed for youth who could not travel long distances to the state ambassador training but still wanted to learn communication skills and become 4-H Ambassadors at the county level. (Gillespie, Bywater, Kent, \& Kimball, 2009).

\section{Program Design}

TALK was developed through a partnership between University of Idaho (UI) Extension faculty, 4-H professionals, youth and volunteers. Each of the planning committee members are responsible for teaching a workshop, as well as coordinating other parts of the weekend retreat. All of the housekeeping, cooking and extra activities are lead by adult volunteer chaperones and participating teens. The United Dairymen of Idaho and local community businesses donate food, supplies and educational materials. Guest speakers have included Miss Rodeo Idaho, a local restaurateur, area Police Departments, local independent business owners, county 4-H teen councils, the Albion Historic Museum curator, State 4-H Ambassador youth and UI student interns.

TALK is held in March at Campus Grove in Albion, ID. The facility is the former Albion State Normal School and encompasses several acres of lawn and a renovated dormitory. It is now a privately owned retreat center. The location is somewhat isolated and space is limited but the retreat "atmosphere" provides a perfect setting to focus on learning valuable life skills while having fun with other teens from across Idaho. TALK is limited to forty-eight teens each year and in three of the first four years registration has been filled, with more teens on a waiting list to attend.

Teens may attend TALK for two years, currently fifty-three youth have returned for the second year although more are expected since the two years do not have to be completed consequently. Workshops offered on even years include writing press releases, creating posters and a personality awareness session. Teens who participate on odd years attend workshops on event planning, goal setting and interviewing skills. At the end of two years, the teens have a completed binder of information called the Teen Ambassador Leadership Kit. Resources about photography, basic 4-H information and other materials from workshops or guest speakers are also included. This "kit" provides the tools teens need to solve some of the challenges they face when promoting and marketing $4-\mathrm{H}$. Ambassador polo shirts and business cards are also provided. In addition to 4-H, TALK participants are encouraged to become involved in other community organizations with active youth and adult partnerships. Flynn, Frick and Steele 
(2010) determined that experiences that contributed most to Montana 4-H alumni becoming involved in community leadership were related to conducting meetings, developing leadership skills and participating in community activities. TALK is providing these life skills for Idaho $4-\mathrm{H}$ teens.

\section{Program Evaluation}

Twenty-nine teens, representing seven counties throughout Idaho registered for the 2009 TALK retreat. In 2010, forty-eight teens (the retreat maximum) representing thirteen counties attended, in 2011, forty-eight teens from fifteen counties participated and in 2012 forty-two teens from fourteen counties attended (Gillespie, Bywater, Kimball, Cummins \& Barfuss 2012).

Participants complete evaluations at the conclusion of the retreat each year. The teens are asked about their experience and how they have used the information. The 4-H professionals are asked to determine the ways teens are using the communication skills they learned and the effectiveness of the TALK retreat. Evaluations strongly indicated a need for this type of training and TALK appears to be successfully meeting that need. Funding for this training has been provided in part by the Idaho Friends of 4-H (4-H Endowment Account). Because the results have shown the program to be beneficial to youth in the state, funding has continued each year for the past five years.

Evaluations completed at the end of the weekend retreat asked participants to rate the registration process, workshops, activities, food and facilities. Teens were asked to list how they planned to use the information they received in the workshops, what was the most useful part of the workshop and suggestions for improvement, $100 \%$ of participants responded.

When asked how they plan to use the information gained at their respective workshops teens replied:

- $\quad$ "I want to be able to teach little kids about how awesome 4-H can be, the things I learned are going to be a huge help."

- "I plan to use it when working with people I have a hard time getting along with."

- "I plan on going out and making my own press releases."

- "In promoting leadership projects in my community."

- "Use it to get more members into the 4-H program."

- "I understand why we think and act like we do; I can better understand someone I didn't get along with."

While planning for the third year, of the program, two questionnaires, using Survey Monkey were developed. The first instrument was for former TALK participants and the second one was for the county 4-H professional in the youth's respective county. The survey for youth participants included questions about when they attended TALK, their age and grade, how they learned about the retreat, why they decided to attend, if they had encouraged others to attend, if they used the TALK materials they received, did they feel prepared to market and promote 4$\mathrm{H}$, and what specifically they had done after attending TALK. The teens were also asked if they wore their Ambassador polo shirts and used the business cards they were provided. Retreat participants were also asked what they thought the three best things were about TALK, the three most useful things about TALK and if there were additional materials that could have been provided to better prepare them to promote and market 4-H when they got home. Survey responses were received from $49 \%$ of the teens who had attended TALK; half had attended in 2009 and half in 2010. 
Some results from the teen's responses include:

- $67 \%$ felt they were prepared to go home and promote 4-H on their own

- $83 \%$ would ask County 4-H staff if they could help with activities

- $33 \%$ were using TALK materials to promote $4-\mathrm{H}$

- $50 \%$ referred to TALK materials to make posters and presentations

- $83 \%$ always wore their Ambassador polo shirt when promoting $4-\mathrm{H}$

- $83 \%$ used their Ambassador business cards

- $100 \%$ promoted, marketed or helped at a 4-H activity because of attending TALK

- $50 \%$ completed county $4-\mathrm{H}$ Leadership projects as a result of attending TALK

According to the comments made by the teen participants, the best thing about attending TALK was:

- Meeting new people who shared my interests

- Learned more about how to be professional

- Making new friends

- Help in writing stories for media

- Gaining new ideas

The most useful things learned at TALK:

- How to make posters

- How to write a story for a newspaper

- How to make a press kit

- Learning about the different personalities of people

- Sharing responsibilities

The most useful things included in TALK materials:

- Dress For Success guidelines

- Business cards

- UI Extension office contact information (emails and phone numbers)

- Personalized notebooks

- Etiquette information

The survey administered to 4-H professionals asked what kind of interaction they had with the teens who returned from TALK, the quality of the help they received from the teens, if the teens used the materials they received at TALK, if they had contacted the TALK teens to help or if not why not, and to name three important skills the teens learned at the retreat or three skills that the teens seemed to be lacking. Surveys were received from 4-H professionals in eleven of the thirteen counties who had teens participating.

Some results from the 4-H staff's responses include:

- $40 \%$ had teens contact them and ask to help with 4-H activities

- $70 \%$ called on TALK teens to come help with $4-\mathrm{H}$ activities

- $20 \%$ thought the TALK teen's quality of help was excellent

- $60 \%$ thought the TALK teen's quality of help was pretty good

- $20 \%$ had no contact with TALK teens

The two 4-H professionals who reported they had no contact with TALK teens or had not asked them to help were then asked why this occurred. The responses received were; "it's easier to do it myself" and "don't really have the energy to engage them." 
4-H staff felt the best skills gained by teens who attended TALK were:

- Confidence

- Willingness to participate, assist and perform public speaking

- Better knowledge of the 4-H program

- Overcoming fear of meeting people

- Enthusiasm

- Better communication skills

- Teamwork

- Setting goals and recognizing steps to accomplishing a task

4-H staff felt the skills lacked by teens who attended TALK were:

- Time management

- How to be a self-starter

- Follow through

- Confidence to ask their Extension office for help or advice

- Why it is important to help your county promote 4-H

\section{Conclusion}

To summarize, the evaluation results indicated youth who attended TALK returned home to help promote 4-H locally and were prepared with the training and materials they received to successfully do so. The local 4-H staff is working with the TALK teens, is appreciative of the training and felt the teens have gained skills such as confidence, willingness to participate, better knowledge of the 4-H program and the ability to speak in front of people.

Because the evaluation results have been so positive and the program continues to grow each year, program organizers have been invited to present workshops at various State Leader's Forums and the Statewide 4-H Trainings. Two UI Extension Impact Statements were also created to share the results of the program with University administration and other relevant stakeholders. The 2011 IAE4-HA State Award for Search for Excellence in Teen Programming was awarded to the Idaho 4-H Teen TALK coordinator. In 2012 the TALK planning committee was awarded the NAE4-HA State and Regional (West) Search for Excellence in Teen Programming Team.

The youth attending TALK are all active 4-H members, but the life skills achieved by participants could be gained at leadership workshops sponsored by other youth development agencies such as Boys and Girls Clubs, church youth groups or Scouts. By following the retreat format developed by the TALK planning committee, goal setting, communication, public speaking and program marketing skills could all be acquired by their participants as well.

\section{References}

Flynn, A., Frick, M., \& Steele, D. (2010). Relationship Between Participation in 4-H and Community Leadership in Rural Montana. Journal of Extension (48:2). On line at: www.joe.org/joe/2010april/rb1.php.

Gill, B.E., Ewing, J.C., \& Bruce, J.A. (2010). Factors Affecting Teen Involvement in Pennsylvania 4-H Programming, Journal of Extension (48:2). One line at: www.joe.org/joe/2010april/pdf/JOE v48 2a7.pdf. 
Gillespie, D.R., Bywater, J., Kent, A., \& Kimball, K. (2009). "Teen Ambassador Leadership Kit" teens learn about TALK. University of Idaho Extension Impact Statement. On line at: http://www.extension.uidaho.edu/impacts/Pdf 09/5-09dgillespie-TALK.pdf.

Gillespie, D.R., Bywater, J., Kimball, K., Cummins, M., \& Barfus, L. (2012). Idaho 4-H teens continue to TALK. University of Idaho Extension Impact Statement. On Line at: http://www.extension.uidaho.edu/impacts/Pdf 12/9-12dgillespie-talk.pdf.

Harder, A., Lamm, A., Lamm, D., Rose III, H., \& G. Rask. (2005). An In-Depth Look at 4-H Enrollment and Retention. Journal of Extension (43:5). On line at: www.joe.org/joe/2005october/rb4p.shtml.

Idaho ES 237. (2012). Annual Extension Youth Enrollment Report. On line at: https://www.uidaho.edu/extension/4h/pages/securefolder/staff/reportingandenrollment.

Lerner, R.M., Lerner, J.V., \& Colleagues. (2011). The Positive Development of Youth, Report of the Findings from the First Eight Years of the 4-H Study of Positive Youth Development. National 4-H Council Marketing and Communications Team. On line at: http://www.4-h.org/about/youth-development-research/positive-youth-development-study/

National 4-H Headquarters at USDA. (Annual 4-H Youth Development Enrollment Report: 2003 Fiscal Year).

Shelstad, N., \& Peutz, J. (2009). 4-H ambassador training: Meeting the needs of youth. University of Idaho Extension Impact Statement. On line at: http://www.extension.uidaho.edu/impacts/Pdf 09/12-09nshelstad-4H.pdf.

(C) Copyright of Journal of Youth Development Bridging Research and Practice. Content may not be copied or emailed to multiple sites or posted to a listserv without copyright holder's express written permission. Contact Editor at: patricia.dawson@oregonstate.edu for details. However, users may print, download or email articles for individual use.

ISSN 2325-4009 (Print); ISSN 2325-4017 (Online) 